\title{
An Implementation Of Electronic Traffic Law Enforcement Against Traffic Violations
}

\section{Dodiawan S. ${ }^{*}$ and Arpangi**)}

*) Police of Sukoharjo, E-mail: dodiawan_mh36@std.unissula.ac.id

**) Faculty of Law Universitas Islam Sultan Agung

\begin{abstract}
This study aims to identify and analyze the implementation of Electronic Traffic Law Enforcement and the obstacles in implementing ETLE in the context of law enforcement against traffic violations at the Blora Police Traffic Unit. The approach method used is sociological juridical, descriptive analytical research specifications, types and sources of data using primary and secondary data, data collection methods are field studies and literature studies, while the data analysis method uses qualitative analysis. The results showed that ETLE implementation is carried out in several stages, starting from CCTV installation, data recording of violators, identification of Smart Resident Center (SRC), sending letters to violators, confirmation, issuing ticket and BRIVA code, to blocking of STNK. This is a manifestation of law enforcement against traffic violations while still paying attention to the principles of justice, legal certainty and expediency. However, in practice there are several obstacles, namely the immediate addition of CCTV installations with adequate camera quality, notifying the vehicle owner that he has committed a violation and to immediately change the name of the vehicle, conducting raid operations on the highway, as well as conducting socialization and education about traffic rules and regulations ETLE.

Keywords: Electronic Traffic; Law Enforcement; Traffic Violation.
\end{abstract}

\section{Introduction}

Globalization and modernization require people to carry out intensive mobilization to facilitate their interactions in economic, social, political, cultural and other interests. Humans are zoon politicons or social creatures, which require social interaction with other people because humans cannot live alone without the help or cooperation of others. Therefore, in the life of society, nation and state, transportation becomes a very important means in supporting mobilization either by two-wheeled vehicles, four-wheeled vehicles, or other road transportation. ${ }^{1}$

The greater the population growth, the denser the mobility in road transportation. According to Soerjono Soekanto, if you want to see the conditions in a country, you only need to see whether the traffic is running safely, comfortably and in an orderly manner or vice versa. In traffic, it can be seen the morals and

\footnotetext{
1Syahruddin, Efektivitas Tindakan Polisi Terhadap Pelanggar Pasal 106 Ayat 5 Undang-Undang Lalu Lintas Dan Angkutan Jalan Mengenai Kelengkapan SIM Dan STNK Pada Kendaraan Roda Dua Dalam Konteks Persamaan Perlakuan di Hadapan Hukum (Studi Kasus di Kabupaten Blora), Jurnal Hukum dan Pembangunan Ekonomi, Vol. 6 No. 1, 2018, url : https://jurnal.uns.ac.id/hpe/article/view/17588
} 
behavior of road users, which can interpret the legal conditions or behavior of a country. ${ }^{2}$

The transportation system greatly determines the effectiveness of a city. The number of cases of traffic violations on the highway by road users tends to result in accidents and increasing traffic congestion. ${ }^{3}$ In the case of traffic violations, motorcycle riders are usually more involved than other vehicle users. ${ }^{4}$

The above conditions make the state take a stand in regulating (regeling) traffic and road transportation, because traffic regulations have a strategic role in supporting development and national integration as an effort to promote public welfare. ${ }^{5}$

On March 23, 2021, the Korlantas Polri implemented the first phase of Electronic Traffic Law Enforcement (ETLE) nationwide. ${ }^{6}$ ETLEis a sophisticated camera system that can detect violations committed by motorists. The camera will record the violation that occurred and then enter it into the database. The camera cancapture any violations that occur. ${ }^{7}$

At the Blora Polres Satlantas, ETLE began to be piloted on March 23, 2021 by relying on Closed Circuit Television (CCTV) cameras installed at three intersection points, namely at the Blora District Attorney's junction, Biandono intersection, Seso intersection in front of Blora Police, as well as monitoring cameras in Grojogan and Blora Pancasila Monument. In practice, there are still some obstacles that arise in the implementation of ETLE including the lack of CCTV camera installation and the lack of camera quality that is not very clear. This can certainly hinder the implementation of ETLE at the Blora Police Traffic Unit.

The implementation of ETLE is a form of transparent law enforcement against traffic violations that apply modern technology. In implementing the law, if there is a violation of the law, the violation must be dealt with by taking legal action as a form of law enforcement carried out by law enforcement agencies authorized by the state. In enforcing the law there are three things that must be considered, namely legal certainty, expediency and justice. Law enforcement is an attempt to make the ideas of justice, legal certainty and social benefits a reality. ${ }^{8}$ This study aims to determine the implementation of Electronic Traffic Law Enforcement in the context of law enforcement against traffic violations at the Blora Police Traffic Unit and the obstacles in implementing Electronic Traffic Law

\footnotetext{
2 Soerjono Soekanto, 1990, Polisi dan Lalu Lintas Analisis Menurut Sosiologi Hukum, Bandung: Mandar Maju, p.1.

${ }^{3}$ Teguh Tri Prasetyo and Eko Soponyono, "Juridical Analysis Of Prosecution Application Against Traffic Violators Through E-Ticketed System With CCTV Footage As Evidence", Jurnal Daulat $\begin{array}{lllll}\text { Hukum, } & \text { Vol. } & 2 & \text { No.1 } & \text { (2019), url }\end{array}$ http://jurnal.unissula.ac.id/index.php/RH/article/view/4216/2922

${ }^{4}$ Bobby Anugrah Rachman, Anis Mashdurohatun and Achmad Sulchan, "Traffic Effectiveness by Law Enforcement Community Through Which are Ticketed Traffic Law in Police of Pekalongan" Jurnal Daulat Hukum, Volume 2 Issue 1, March 2019, url: http://jurnal.unissula.ac.id/index.php/RH/article/view/4216/2922

5Soehino, 2008, Ilmu Negara, Third Edition, Yogyakarta: Liberty, p. 148.

6 Rosy Dewi Arianti Saptoyo, Tilang Elektronik ETLE Berlaku Nasional, Perhatikan 4 Hal ini, https://www.kompas.com, accessed 15 April 2021

${ }^{7}$ Ini Perbedaann ETLE dan e-tilang, https://prfmnews.pikiran-rakyat.com, accessed 15 April 2021).

8 Satjipto Rahardjo, 2011, Penegakan Hukum Progresif, Jakarta : Ghalia Indonesia, p.14
} 
Enforcement in the context of law enforcement against traffic violations at the Blora Police Traffic Unit and the solution.

\section{Research Methods}

The approach method used in this research is sociological juridical, namely:research based on normative legal science and examines how the law works in society. ${ }^{9}$ The research specification is analytical descriptive, the sources and types of data used are primary data and secondary data. The data collection method is carried out through field studies and literature studies while the data analysis method uses qualitative analysis.

\section{Results and Discussion}

\subsection{Implementation of Electronic Traffic Law Enforcement}

ETLE is an effort to implement technology to record traffic violations electronically to support security, safety and order. The implementation of ETLE was first piloted on October 1, 2018 and is currently being implemented nationally. The purpose of implementing ETLE is to minimize parties who commit extortion when taking action against traffic violations and to improve driving discipline. ${ }^{10}$

Technically, after being caught on a CCTV camera violating traffic rules, then the data is processed to issue a traffic violation confirmation letter accompanied by a photo of the violator sent to the address of the violator through PT Pos according to the motorized vehicle number. In the event that the violator does not confirm within 14 days after the letter is received, the STNK will be blocked. On the other hand, if you confirm, you will be given a ticket. The payment of the fine can be through Bank BRI or PT Pos or following a trial at the local District Court. ${ }^{11}$

Prior to the implementation of the National ETLE, the Blora Polres Satlantas had implemented the E-Tilang (Electronic Ticket) program issued by the National Police Headquarters to improve public services and reduce the practice of illegal levies (extortion). Everyone who commits a violation will be given a ticket form from the Blora Police Traffic Unit and immediately pay the fine at the bank by showing a ticket. ${ }^{12}$

\footnotetext{
${ }^{9}$ Mukti Fajar ND and Yulianto Achmad, 2013, Dualisme Penelitian Hukum Normatif dan Empiris, Yogyakarta: Pustaka Pelajar, p.47.

${ }^{10}$ Media Indonesia in Noverdi Puja Saputra, "Electronic Traffic Law Enforcement (ETLE) dan Permasalahannya”, Info Singkat, Vol. XIII, No.7/I/Puslit/April/2021, url : https://sdip.dpr.go.id/search/detail/category/Info\%20Singkat/id/1175

11 Satlantas Polres Bora Uji Coba Penerapan Tilang Elektronik, https://haloblora.com, accessed April 15, 2021.

12 Riyanto, Umar Ma'ruf and Sri Kusriyah, Implementation Of Police Role In Countermeasures Of Traffic Criminal Acts Of Traffic Violations In Efforts To Establish Police Images As Community Guidelines, Jurnal Daulat Hukum, Volume 3 Issue 2, June 2020, url : http://jurnal.unissula.ac.id/index.php/RH/article/view/9385/4154
} 
Currently, the Blora Polres Satlantas has implemented ETLE in its jurisdiction since March 23, 2021 with the following stages: ${ }^{13}$

- CCTV installation In the jurisdiction of the Blora Police, CCTV has been installed in three locations, namely at the Blora District Attorney's T-junction, the Biandono intersection, the Seso intersection in front of the Blora Police, Grojogan and the Blora Pancasila Monument. The cameras were installed using facilities from the Blora Regency Government through the Department of Transportation.

- Violator data recording Motorized vehicle drivers who violate traffic will be recorded on CCTV, so that it can be clearly identified the type of violation committed and the license plate of the violator's motor vehicle according to the address listed in the STNK

- Smart Resident Center (SRC) identification

Officers identify violators' data through SRC. From the license plate of the vehicle recorded by the camera, data from the ownership of the vehicle will appear.

- Sending letters to violators

The officer will send a letter of evidence of violation via POS to the alleged violator according to the address listed in the STNK and BPKB for a confirmation request for the violation that occurred. The confirmation letter is the first step of taking action, where the vehicle owner is required to confirm the ownership of the vehicle and the vehicle driver at the time of the violation.

- Confirmation

Suspected traffic violators can confirm to the officer, if the vehicle in question has become a vehicle belonging to someone else, it must be confirmed immediately. In this case the Blora Polres Satlantas also opened a hotline service and a WhatsApp number to confirm if the violator felt he had not committed a violation. If the alleged violator does not confirm to the police officers within the time limit, the STNK will be blocked.

- Giving Tickets and BRIVA Codes

Traffic violators who have confirmed will be given a ticket along with the BRIVA code as a virtual code to pay the ticket at BRI bank.

- STNK blocking

In the event that the traffic violator does not make the payment as stated in the ticket, the police officer will automatically block the STNK on behalf of the owner.

Law enforcement efforts against traffic violations through ETLE are an effort to realize justice, legal certainty and social benefits. In Aristotle's view, justice is a granting of equal rights but not equality. Aristotle distinguishes equal rights according to proportional rights. Everyone or every citizen is equal before the law. ${ }^{14}$ The application of ETLE in law enforcement against traffic violations has fulfilled the principle of justice. The implementation of ETLE does not discriminate

\footnotetext{
13 Interview with AKP Edi Sukamto as Kasatlantas Polres Blora, June 30, 2021.

${ }^{14}$ Carl Joachim Friedrich, 2004, Filsafat Hukum Perspektif Historis, Bandung : Nuansa dan Nusamedia, p. 24
} 
on who violators will be given sanctions because the action is carried out transparently.

The implementation of ETLE has also complied with the principle of legal certainty. Legal certainty two meanings, namely the existence of general rules that make individuals know what actions may or may not be done; and in the form of legal security for individuals from government arbitrariness because with the existence of general rules, individuals can know what the state may charge or do to individuals. ${ }^{15}$ The existence of Act No. 22 of 2009 concerning Road Traffic and Transportation confirms what forms of traffic violations and sanctions are. With the evidence of CCTV footage, it is clear the type of violation committed by the violator, then the officer sends a letter of evidence of violation to be confirmed. This has fulfilled the principle of legal certainty.

The implementation of ETLE has clearly provided benefits to the community. ETLE is not just a tool to take action and reduce the number of traffic violations. The main purpose of implementing ETLE is to create a culture of orderly traffic so that people are expected to be more disciplined in traffic even without the presence of the police in the field. This can eventually be realized security, safety, order and smoothness (Kamseltibcar) traffic.

\subsection{Obstacles in the Implementation of Electronic Traffic Law Enforcement and Solutions}

The implementation of ETLE at the Blora Police Traffic Unit experienced several obstacles, namely as follows: ${ }^{16}$

- Lack of CCTV facilities

The lack of CCTV facilities both in quantity and quality is a separate obstacle in the implementation of ETLE. It is known that only 5 cameras have been installed, namely the Blora District Attorney's T-junction, the Biandono intersection, the Seso intersection in front of the Blora Police, Grojogan and the Blora Pancasila Monument. This amount certainly does not cover the entire area of Blora Regency. In addition to the lack of CCTV cameras, the quality of the cameras is still low. This can impede the identification of the license plates of the offending vehicle.

The solution to overcome this is the need for additional CCTV installations at each location point that can reach the entire Blora Regency area. In addition, the quality of CCTV must be adjusted to the needs so that it is adequate for vehicle data identification.

- There are vehicles that have changed ownership but have not been renamed

There are several traffic violators caught on CCTV cameras that have changed ownership. This happens because the first owner of the vehicle has sold his vehicle to another party and has not been renamed. As a result, when the vehicle number plate is identified, the officer will send a proof of traffic violation to the owner of the old vehicle. In some cases the owner of the old

\footnotetext{
${ }^{15}$ Riduan Syahrani, 1999, Rangkuman Intisari Ilmu Hukum, Bandung : Citra Aditya Bakti, p. 23.

${ }^{16}$ Interview with AKP Edi Sukamto as Kasatlantas Polres Blora, June 30, 2021.
} 
vehicle did not confirm. As a result, the vehicle's STNK is blocked, while the new vehicle owner does not know that the vehicle's STNK has been blocked.

The solution to overcome this is to notify the new vehicle owner that his vehicle has committed a traffic violation, when the new vehicle owner pays the Motor Vehicle Tax. In addition, new vehicle owners are asked to change the name of the vehicle. 
- The vehicle does not have a valid document (illegal)

Some vehicles operating in the jurisdiction of the Blora Police Station do not have valid documents (illegal). This can be seen at the time of identification, the vehicle number plate cannot be identified or unknown. The solution to overcome this is to carry out raid operations on the highway, because in this operation an inspection will be carried out on the completeness of vehicle documents.

- Traffic violators do not confirm

Traffic violators who have received a letter of evidence of violation there are those who do not confirm to the officers either directly or through the Hotline or Whatshap service. This could be because violators or the public in general do not know about the implementation of ETLE in Blora.

The solution to overcome these obstacles is to intensively conduct socialization and education about traffic order and ETLE to the public either through social media, direct socialization is also carried out to road users such as distributing safety brochures and pamphlets, and also installing banners in crowded places.

\section{Closing}

The implementation of ETLE is carried out in several stages, starting from CCTV installation, data recording of violators, identification of the Smart Regident Center (SRC), sending letters to violators, confirmation, issuing ticket tickets and BRIVA codes, to blocking vehicle registration. This is a manifestation of law enforcement against traffic violations while still paying attention to the principles of justice, legal certainty and expediency. However, in practice there are several obstacles, namely the immediate addition of CCTV installations with adequate camera quality, notifying the vehicle owner that he has committed a violation and to immediately change the name of the vehicle, conducting raid operations on the highway, as well as conducting socialization and education about traffic rules and regulations. ETLE. The suggestions put forward are for the Blora Police Traffic Unit to immediately add CCTV installations of adequate quality; and for the community, there should be more discipline in traffic for the sake of creating security, order and smoothness in traffic.

\section{References}

\section{Journal}

[1] Bobby Anugrah Rachman, Anis Mashdurohatun and Achmad Sulchan, "Traffic Effectiveness by Law Enforcement Community Through Which are Ticketed Traffic Law in Police of Pekalongan" Jurnal Daulat Hukum, Volume 2 Issue 1, March 2019, url: http://jurnal.unissula.ac.id/index.php/RH/article/view/4216/2922.

[2] Noverdi Puja Saputra, "Electronic Traffic Law Enforcement (ETLE) dan Permasalahannya", Info Singkat, Vol. XIII, No.7/I/Puslit/April/2021, url: https://sdip.dpr.go.id/search/detail/category/Info\%20Singkat/id/1175 
[3] Riyanto, Umar Ma'ruf and Sri Kusriyah, Implementation Of Police Role In Countermeasures Of Traffic Criminal Acts Of Traffic Violations In Efforts To Establish Police Images As Community Guidelines, Jurnal Daulat Hukum, Volume 3 Issue 2, June 2020, url : http://jurnal.unissula.ac.id/index.php/RH/article/view/9385/4154.

[4] Syahruddin, Efektivitas Tindakan Polisi Terhadap Pelanggar Pasal 106 Ayat 5 Undang-Undang Lalu Lintas Dan Angkutan Jalan Mengenai Kelengkapan SIM Dan STNK Pada Kendaraan Roda Dua Dalam Konteks Persamaan Perlakuan di Hadapan Hukum (Studi Kasus di Kabupaten Blora), Jurnal Hukum dan Pembangunan Ekonomi, Vol. 6 No. 1, 2018, url : https://jurnal.uns.ac.id/hpe/article/view/17588

[5] Teguh Tri Prasetyo and Eko Soponyono, "Juridical Analysis Of Prosecution Application Against Traffic Violators Through E-Ticketed System With CCTV Footage As Evidence", Jurnal Daulat Hukum, Vol. 2 No.1 (2019), url : http://jurnal.unissula.ac.id/index.php/RH/article/view/4216/2922

\section{Internet}

[1] Ini Perbedaann ETLE dan e-tilang, https://prfmnews.pikiran-rakyat.com, accessed on 15 april 2021.

[2] Media Indonesia dalam Noverdi Puja Saputra, "Electronic Traffic Law Enforcement (ETLE) dan Permasalahannya", Info Singkat, Vol. XIII, No.7/I/Puslit/April/2021.

[3] Rosy Dewi Arianti Saptoyo, Tilang Elektronik ETLE Berlaku Nasional, Perhatikan 4 Hal ini, https://www.kompas.com, accessed on 15 April 2021

[4] Satlantas Polres Bora Uji Coba Penerapan Tilang Elektronik, https://haloblora.co, accessed on 15 April 2021.

\section{Books}

[1] Carl Joachim Friedrich, 2004, Filsafat Hukum Perspektif Historis, Bandung : Nuansa dan Nusamedia.

[2] Mukti Fajar ND dan Yulianto Achmad, 2013, Dualisme Penelitian Hukum Normatif dan Empiris, Yogyakarta: Pustaka Pelajar.

[3] Riduan Syahrani, 1999, Rangkuman Intisari Ilmu Hukum, Bandung : Citra Aditya Bakti.

[4] Satjipto Rahardjo, 2011, Penegakan Hukum Progresif, Jakarta : Ghalia Indonesia.

[5] Soerjono Soekanto, 1990, Polisi dan Lalu Lintas Analisis Menurut Sosiologi Hukum, Bandung: Mandar Maju.

[6] Soehino, 2008, Ilmu Negara, Edisi Ketiga, Yogyakarta : Liberty.

[7] Wirjono Prodjodikoro, 2003, Asas-Asas Hukum Pidana di Indonesia, Bandung : Refika Aditama.

\section{Regulation}

[1] Act No. 2 of 2002 concerning the Indonesian National Police.

[2] Act No. 22 of 2009 concerning Road Traffic and Transportation. 